\title{
Universiteit
}

Leiden

The Netherlands

\section{From Tamanrasset: the struggle of Sawaba and the Algerian connection, 1957-1966}

Walraven, K. van

\section{Citation}

Walraven, K. van. (2005). From Tamanrasset: the struggle of Sawaba and the Algerian connection, 1957-1966. The Journal Of North African Studies, 10(3/4), 507-527. Retrieved from https://hdl.handle.net/1887/9511

Version: $\quad$ Not Applicable (or Unknown)

License: $\quad$ Leiden University Non-exclusive license

Downloaded from: https://hdl.handle.net/1887/9511

Note: To cite this publication please use the final published version (if applicable). 
13. I. Schmitz, 'Le souffie de la parenté. Mariage et transmıssion de la Baraka chez les clercs musulmans de la Vallée du Sénégal', L'Homme 154 (2000), p. 11.

14. J. Boulègue, 'La participation possible des centres de Pir et de Ndogal à la révolution islamique sénégambienne de 1673' in J. Boulègue (ed.), Contributions à l'hustoire du Sénégal, Parts, Centre de Recherches Africaines, Cahiers du CRA 5, (1987), pp. 119-125.

15. Ould Cheik (note 2); Webb (note 4).

16. J.L. Balans, 'Le système politique maurtanen', in Collectif, Introduction à la Mauritanie, (Paris: CNRS 1979), pp. 316-317.

17. The core of the speech was as follows: 'I therefore call on our brothers in the Spanish Sahara to dream of this economic and spiritual Greater Mauritania of which we cannot speak at present. I address to them and I ask you to repeat to them a message of friendship, a call for concord between all the Moors of the Atlantic, in Azaouad and from the Draa to the borders of Senegal'. Archives of the Ministry of Foreign Affairs, 'Discours du Vice-Président du Conseil de Gouvernement de la Mauritanie', typescript copy (Nouakchott 1/7/1957), p. 2 .

18. Balans (note 17)

9. President Ould Taya was removed from power on August 32005 in a military coup, after this article

was written (translator).

. The current enthusiasm of mining companies and their strong presence in Maurtania since mining laws were eased and the legal framework underwent major reforms attest to this. More than two hundred

mining exploration permits, not including oil exploration permits, have been granted to date.

. Abdallahi Fall, 'L'espace mauritanien et son rôle dans le commerce caravanier médiéval transsaharien', Al Mawqib Eth Thaqafi 6-8 (1996), pp. 16-20.

For a study of this tribal confederation which is considered to be a major nomadic tribe see Caratini (1993), particularly Les fils des nuages, Paris, Seuil, 1993.

23. As the weekly magazine Le Calame 171 (10/3/99) pointed out.

According to Membé, 'In many cant privé indirect', Politique africaine 73 (mars 1999), p. 113. According to Membé: 'In many cases, the distinction between the formal fixed location of frontiers tually everywhere, economic and cultural character is growing. Patterns of conflict have emerged vircally disadvantaged by a majority of allogenou to have rights to land consider themselves economiand the renvention of through the manipultion of inhertances and through the manipulation of the ideology of local origin and kin descent'.

\section{From Tamanrasset: The Struggle of Sawaba and the Algerian Connection, 1957-1966}

\author{
KLAAS VAN WALRAVEN
}

This article deals with the rebellion of 'Sawaba' against the PPN regime in Niger. Sawaba was a political party that represented a social movement and formed the first autonomous government of Niger during the last years of French suzerainty (1957-1958). For a number of reasons, related to the war in Algeria and the rise of the Fifth Republic, the French assisted in Sawaba's removal from government. Together with the new regime, they proceeded to persecute the Sawaba party, which was driven underground. Sawaba organised a clandestine domestic opposition and made preparations for a violent take-over with the help of friendly countries such as Ghana, Algeria and Mali. Assisted with arms, money and training, its comcountries such as Ghana, Algeria and Mali. Assisted with arms, money and training, its com-
mandos invaded Niger from the south and west in the autumn of 1964 . Despite Algerian mandos invaded Niger from the south and west in the autumn of 1964 . Despite Algerian
support before the invasion, the revolt failed and Sawaba was condemned to the political wild-
erness. This article focuses on the Algerian dimension of the revolt. It discusses the political erness. This article focuses on the Algerian dimension of the revolt. It discusses the political evolution of Niger from the spring of 1957 to independence in August 1960 and how this connected to developments in Algeria. It then discusses Niger's security situation and how this was linked to control over its nomadic population and incursions made by the two countries across their common frontier. Subsequent sections analyse Sawaba's clandestine organisation and the support provided by Algeria, discussing Sawaba's cell in Tamanrasset and its military training
further to the north. The conclusion assesses the consequences of the failure of the revolt to the further to the north. The conclusion a between Niger and Algeria.
relans

\section{Introduction}

It has often been said that the Sahara, rather than a barrier, has been a conduit for communication between North and sub-Saharan Africa. Thus, it is no coincidence that during the era of decolonisation political developments in two countries on opposite sides of the desert were closely bound up with each other, i.e. Algeria and Niger. This article argues, in this respect, two central points. Firstly, the history of Niger's accession to formal independence (1960) cannot be fully understood without considering political developments in Algeria and, beyond, those in metropolitan France. Secondly, it is contended that, during the first half of the 1960s, Niger's state security hinged to a considerable extent on its relations with its own domestic opposition, the 'Sawaba' party. This party had been outlawed in the late 1950 s and received the backing of the Algerian government, thereby complicating Niger's relations with Algiers.

Klaas Van Walraven is a political scientist and member of the Research Staff at the African Studies Centre Leiden. He has publishel widely on conflct, resistance and international interventions in Africa and currently working on a mon

The Journal of North African Studies, Vol.10, No.3-4 (September-December 2005) pp.507-527 ISSN 1362-9387 print/1743-9345 online

DOI: $10.1080 / 13629380500336839 @ 2005$ Taylor \& Francis 
This article outlines the Algerian connection of the struggle of Sawaba, which formed Niger's first autonomous government while still under French rule (March 1957-September 1958). It was evicted from political power nearly two years before the onset of independence. Sawaba's short-lived rule was characterised by a rather unstable coalition government made up of Sawaba proper and the 'Bloc Nigérien d'Action' (BNA). The BNA received its main backing from conservative, 'neotraditional' chiefs in the eastern, Hausa-speaking regions of the country. In contrast, Sawaba drew its support from a broad range of social categories, though especially from rural folk who had broken the confines of village life and were staking out a new life in low-status jobs in Niger's urban areas. These groups resented the power that the chiefs still exerted over rural society. Sawaba's government, headed by the charismatic, left-leaning nationalist Djibo Bakary, was also confronted with the destructive opposition of the 'Parti Progressiste Nigérien' (PPN), whose support came from higher placed 'évolués', or western educated public employees, from the Zerma- and Songhay-speaking regions in the west of Niger. By April 1958 the government and PPN were on a collision course. When the PPN tried to break into its power base the government, spurred on by its radical wing and revolutionary nationalist programme, staged a full-scale attack on PPN cadres in the capital Niamey, thereby successfully subduing the party.

Yet, barely one month later, events in Algeria intervened from a distance. In an ultimate attempt to maintain control over the country French colonists and military sympathisers established 'Comités de salut public', which came down to an attempted coup d'état, not just in Algeria but also against the government in metropolitan France. Within a fortnight, this led to General De Gaulle assuming full powers in France for a period of seven months, during which he prepared the advent of the Fifth Republic and, in the process, a complete overhaul of the French colonial empire. In order to provide this transformation with the requisite political legitimacy, a referendum was to be organised in September 1958 in which both the French and the peoples in the colonies could express themselves. Since a 'No' vote would detract from the legitimacy of the Fifth Republic to be officially inaugurated in January 1959 and, with it, of De Gaulle's political establishment, France's metropolitan and colonial bureaucracies were under pressure to achieve a positive outcome at some cost. ${ }^{1}$ This was particularly true for Niger, which for a number of reasons was considered of great strategic importance.

As the Sawaba government found it politically impossible to go along with the new constitutional structure, it found itself pitted squarely against the most powerful interests in France. Assisted by the French military in Algeria and the federal authorities of 'Afrique Occidentale Française' (AOF) in Dakar, a tough new colonial governor, specially appointed for the purpose, intervened to influence the referendum's outcome in Niger. In a humiliating move, he emasculated the Sawaba government, in the process disabling 1ts campaign for a 'No' vote and manipulating the referendum's outcome. ${ }^{2}$ The French obtained the desired electoral approval, forced Bakary to resign and organised new parliamentary elections, which, under similar circumstances, led to a victory for the PPN in December 1958. The PPN was allowed to form a new government and in a joint effort the French and PPN began to drive Sawaba underground. By the autumn of 1959 , the party had been banned and party cadres forced into exile or driven into clandestine existence.

Sawaba then began to organise underground, receiving support for this from countries whose governments shared its outlook: Mali, Ghana - and Algeria's 'Front de Liberation Nationale' (FLN). Through this, it was able to organise, besides clandestine opposition at home, a number of cells abroad with which to infiltrate and agitate in Niger. The party opened offices in Bamako, Accra, and Algiers, while cells to collect intelligence and undertake infiltrations were established closer to Niger's borders in Gao (Mali), Kano (Nigeria) and Tamanrasset (Algeria). Military training took place at camps in Ghana, further afield in communist China and North Vietnam, and in the city of Marnia in Algeria. By the autumn of 1964 Sawaba's leadership launched a full-scale invasion, across Niger's western and southern borders, from Nigeria, Dahomey (Benin) and Upper Volta (Burkina Faso). Yet, with some exceptions, its attacks failed completely. Sawaba's 'commandos', as they were called, were defeated, rounded up or repulsed. Renewed guerrilla infiltrations continued until the summer of 1966, petering out slowly, with the party's remaining cadres banned to the political wilderness. At the time, these events were considered a mere footnote. ${ }^{3}$ Smothered by the silence of Niger's regime and its French backers, the history of Sawaba's rebellion remained untold and was never researched from a scholarly perspective.

In focusing on the Algerian dimension of Sawaba's rebellion this article ${ }^{4}$ discusses, first, the developments in Niger from the spring of 1957 to the accession to independence in 1960 and how this was connected with developments in Algeria. It then discusses Niger's general security situation, outlining the mutual incursions made by the two countries across the common frontier. Subsequent sections sketch Sawaba's clandestine organisation and the political and military support that Algeria provided to Sawaba, discussing its cell in Tamanrasset and its training further to the north, in Marnia and Algiers. The concluding section will assess the consequences of the failure of Sawaba's revolt to the relations between Niger and Algeria.

\section{Sawaba and Niger's Chequered Decolonisation}

As a political party, Sawaba agitated for higher wages and better working conditions of urban workers, credit facilities for market people, more rights for trade unions, lower taxes, better prices for groundnut farmers and an end to the abuse of peasants by chiefs in the countryside. The core of its membership consisted of so-called 'petit peuple', rural folk who were exploring the widening horizons of a cautious modernisation that had led them to Niger's emergent urban communities, though without permanently breaking ties with their rural homes. In carving out a new existence most occupied modern, but fairly low-status urban functions. These people included a broad range of lower placed groups like 'bellas' (people of slave origin), petty traders and market workers; all manner of craftsmen; low-level civil servants or petty employees, like mailmen and postal workers, bookkeepers, office boys, domestic servants and orderlies; as well as shop assistants, barmen, bakers, boxers, 
and, lower down the social ladder, agricultural labourers like suburban vegetable growers, workers in the construction industry and prostitutes. A special category of Sawaba supporters was formed by transport workers such as porters, bus boys or 'cocksers' (recruiters of clients), bus or lorry drivers and mechanics - people who, like postal workers, were extremely useful in spreading the party message and when it went eventually underground, for collecting intelligence. ${ }^{5}$

On the other hand, Sawaba also included members from higher social echelons, like teachers (though most of these were in the PPN), agronomists, some rich traders, vets, veterinary workers, and nurses. While the party leadership usually involved people with higher education, it also included some semi-literates who had worked their way up through union agitation. ${ }^{6}$ Moreover, it also counted among its following several chiefs (in some western towns) and marabouts, besides peasants, rural teachers and cattle traders. These chiefs, while certainly a minority in the party, also suggest that Sawaba had a broader geographical scope than was often made out, not least because its core of semi-urban small folk could be found throughout the country, in all major and minor urban centres. It was not simply, as has often been argued, a party from the Hausa-speaking east, even if the eastern towns of Zinder and Tessaoua constituted the party's most important strongholds.

Thus, in encompassing this broad range of social categories Sawaba could lay some claim to constituting an emergent social movement, which was aspiring to comprehensive change of Niger's social order. In the political landscape of the late 1950s, it was the only political formation that built on this role, even though the social categories it encompassed did not add up to a numerical majority. The struggle between Sawaba and the PPN was, therefore, more than a power struggle between two political parties fired by the personal ambitions of their leaders. ${ }^{7}$ Consequently, the party's discourse was militantly anti-colonial with undertones of Marxist-inspired revolutionary language that catered to the aspirations of semi-urban marginals, in particular targeting the chiefs and, more broadly, attacking colonial rule. ${ }^{8}$

Since Sawaba had formed a coalition with the BNA, made up of high rank chiefs and évolués, this engendered considerable instability. This was also stimulated by the natural tension that developed between Sawaba's leadership and the party faithful, when the former acceded to the responsibilities of government, under the 'Loi Cadre' - a colonial reform bill - in May 1957. At Sawaba's congress that month, party militants vigorously denounced Niger's chiefs, leading to simmering discontent in the BNA. ${ }^{9}$ In the midst was Djibo Bakary, who as prime minister tried to balance these divergent tendencies. Although he had wished for some sort of entente with the PPN, this was prevented by BNA leaders and the majority of Sawaba partisans, who in victorious fervour monopolised practically all parliamentary and government posts. Belated concessions by Bakary could not entice the PPN, which, marginalised by Bakary's superior manoeuvring, ${ }^{10}$ embarked on a destructive opposition campargn. ${ }^{11}$

By early 1958, relations between Sawaba and the PPN deteriorated sharply. ${ }^{12}$ During the entire month of April, clashes took place between party adherents across the country. The PPN tried to break into Sawaba's eastern strongholds, party organs traded insults, meetings were disrupted and people from both sides subjected to abuse from more or less organised armed groups. By the 22nd a first subril heat. Spurred on by party radicals, ${ }^{13}$ the Sawaba government decided to tighten its grip. Spurred on by party radicals, the Sawaba governey, which had a substantial Armed militants began to patrol the streets of Niamey, which had a substantial party presence but was in majority PPN. Bellas employed as manual labourers were given lorries to patrol the city, visiting compounds of PPN officials - some were given lorries to patrol the city, - leading to violent clashes, shootings, two deaths and numerous injuries. Sawaba's government was deeply implicated in these events, ministers and partisans alike boasting how they had cowed the opposithese events, ministers and partisans alike boasting how the heatest difficulty tion. French-led forces, hampered by a lack of intelligence, had the greatest diffculty in regaining command. ${ }^{14}$ These events showed that Niger threatened to slip from French control, ${ }^{15}$ a development that found its initial logic in the 'Loi Cadre' that set France's African territories on a course of political evolution but had now gone well beyond its limits. Although colonial administrators opposed further devolution, ${ }^{16}$ a metropolitan civil servant investigating the April riots pondered on the possition, ${ }^{16}$ a metropolitan civil servant investigating the bility of some sort of French withdrawal, arguing that

The Algerian crisis of May 1958, however, changed the entire strategic context The Algerian crisis of May 1958 , how control. Niger was not just another French leading to a reassertion of full French control. Niger was no just anseen colony. Though extremely poor, it occupied a strategic position between West and North Africa. Its long border with Algeria served as a conduit for arms and funds North Africa. Its long border with Ance had at least the sympathy of the Sawaba authto the FLN, ${ }^{18}$ whose war against France had at least the sympathy of the Sawa could become a base orities. ${ }^{19}$ French officials feared that, once independent, Niger could become a base for FLN operations. In addition, the country had important sub-soil resources, of which the most vital was uranium, the presence of which was confirmed in 1956 . Uranium played a crucial role in De Gaulle's strategic designs for a nuclear 'force de frappe', to be tested in the Algerian desert. ${ }^{21}$ Niger could also serve as an obstacle to Sanusi Islamic orders, whose expansion southwards from Libya, could disrupt French influence. Finally, Niger could block the influence of its powerful neighbour French influence. Final of French officialdom, ${ }^{22}$ enhanced by the promise of Nigeria's Nigeria, an obsession of French officialdom, enhanced by the pro and members of the independence for 1960 and the growing contacts between Sawaba and mestion party in Northern
'Northern Elements Progressive Union' (NEPU), an opposition Nigeria.

Thus, the idea that Niger could slip from French control represented a worst-case scenario for the more resolute political administration coming in with the Fifth scenario for the more resolute political ant that Niger simply had to agree to De Republic. To this group of people it meant that Niger simply had to agree to De Gaulle's new constitutional structures, which tied France and its overseas colonies together in a so-called 'Communauté' that conceded autonomy but stopped well short of independence. However, political opinion among Sawaba's progressive short of sindependence. However, political opinion anong 'indépendance' was wing had developed to such an extent that nothing else than 'indépendance' Was acceptable. The word came out at an international conference of African politica acceptable. The word came (Dahomey) in July 1958. Spurred on by Sawaba's revolutionary parties in Cotonou (Dahomey) in July 1958. Spurred on by inspiration, it called for immediate independence with retention of the inter-territonal structures of France's federated colonial possessions in West Africa (AOF), a project structures of France's federated the eleventh hour the right to independence was 
inscribed, rather conditionally, in the definitive constitution, it was clear that De Gaulle saw the call for independence as 'secession', i.e. an anti-French step to be met with retribution. ${ }^{23}$

The problem for Bakary was that he could not simply back down. ${ }^{24}$ Although political consciousness about this issue had not reached all corners of Niger, many of Sawaba's followers had been aroused by its agitation. The very name of the party, derived from the word ' $s a w k i$ ' - which approximates the English 'alleviation' - pointed to a popular yearning for relief from misery, represented in the social movement that the party and its socio-political programme tried to embody. ${ }^{25}$ In the effervescent climate of 1958 , it stood for the achievement of a better future for the African majority, prosperity and a degree of political dignity which many felt had to be wrested from the paternalism ingrained in continued French control. The Cotonou conference had therefore considerably enhanced Bakary's prestige among his followers. ${ }^{26}$

Consequently, Bakary and his party were opposed to France's neo-colonial presence implied in the Communauté and its attempt to retain control of parts of the Sahara, for which a common administration, which would detach Niger's Saharan region, was being established. ${ }^{27}$ In a similar vein, Sawaba criticised France's intention to test nuclear weapons in the Algerian part of the Sahara. ${ }^{28}$ It made clear that it wished Niger to engage in cordial economic relations with the French, but only after the accession to independence when agreements could be negotiated on a more equal footing. Sawaba issued assurances that Niger would not look for foreign aid elsewhere, unless forced to. While French intelligence showed awareness of how Sawaba would vote in the referendum on the Communaute ${ }^{29}$ the French political establishment refused to take its ideological statements seriously and wishfully hoped Niger's government would in the end back down. The incoming administration of the Fifth Republic, pressed by time pressure to finalise the constitutional transformation, ${ }^{30}$ in effect expected its African territories to accept the new structures lock, stock and barrel, ${ }^{31}$ no negotiations on content being possible. While De Gaulle did not expect the Communauté to endure for ever, its essence was to safeguard French influence. ${ }^{32}$

The uncompromising attitude with which the project was pushed through was closely tied to the situation in Algeria. Thus, none other than General Raoul Salan, chief of staff of the French forces in Algeria and metropolitan representative there, suggested the French should 'aider financièrement campagne pour le oui au Niger ${ }^{33}$ Salan later admitted in his memoirs that his actions went well beyond his prerogatives, since the sub-Saharan territories did not fall under his authority. In the struggle to contain the FLN, however, he regarded it indispensable that " $l e$ Sahara soit complètement français' and 'les pays riverains $d u$ sud ... votent "oui". ${ }^{34}$ The day after the Sawaba government announced its official stance, Salan sent General de Crèvecoeur to Tamanrasset to confer with General Manière, who was ordered by the military authorities in Dakar to go to the southern Algerian town, upon Salan's explicit suggestion, to discuss the 'prognostics' of the referendum in Niger and Soudan (Mali). With the approval of the federal authorities in Dakar, Salan's plan was put into action. General Manière went on a reconnaissance mission and reported back to Salan that he thought it possible, in Niger, to 'renverser la situation en faveur du "oui". 35 Salan later admitted to having disbursed 'gros moyens' to this end and claimed that this aid had proved crucial to the referendum's outcome. ${ }^{36}$ Thus, it was not only direct metropolitan funds ${ }^{37}$ that were expended to influence the referendum's outcome in Niger but also funds transferred from, or at least through, the French in Algeria. It has even been suggested that the disbursement of metropolitan credit was commenced only after the French generals had met in Tamanrasset. $^{38}$

With interventions from various levels in the French administration, the referendum in Niger led to a majority vote for 'Yes' ${ }^{39}$ Parliamentary elections, while constitutionally unnecessary, were forced through to evict Sawaba from government and led to a PPN-dominated territorial assembly that participated in the election of De Gaulle to the Presidency of the Fifth Republic. ${ }^{40}$ The Sawaba party - faced with the hostility of the French administration, the PPN and many of Niger's principal chiefs, who had been antagonised by Sawaba's rank and file - was crushed. De Gaulle not only obtained the legitimation of his accession to power that year, marred only by the 'defection' of Guinea, but with Sawaba driven underground he was assured of Niger's subjection to French influence. 'Air [would] not go to Moscow, ${ }^{41}$

\section{Algeria and Niger's Security at Independence}

With Sawaba forced underground, the PPN regime became vulnerable to subversive activities on the part of its rival. Opportunities for this were legion, as Niger's society was fractured along lines of cultural identity, the potentially most problematic being the position of the different nomadic groups in the country, such as Peul, Toubou and Tuareg. Fearful of becoming subject to the country's majority sedentary peoples, many Tuareg leaders had expressed reservations about Niger's independence (1960), which, despite membership of the Communaute, was an inevitable outcome of West Africa's inexorable political evolution. Nomadic groups jealously tried to guard what was left of their autonomy and ways of life, which included such potentially subversive activities as gun-running, smuggling and, especially among eastern Toubou groups, raiding. These problems were compounded by developments in Algeria. It was not long before De Gaulle made his fundamental U-turn and embarked upon the process of handing the country over to the FLN, though not without retaining control of nuclear installations at In Eker, just north of Tamanrasset. ${ }^{42}$ The FLN began to expand southwards, testing its influence, not just in Algeria proper but also across the front1er, in Mali and Niger.

It constructed an intelligence network consisting of 'antennas' in the Malian towns of Gao, Kidal, Tessalit and the capital Bamako, and in Niger in both Niamey and Agades. An FLN representative based in Niamey frequently went to Gao to mobilise funds among local Algerians. ${ }^{43}$ However, having not won much popularity among the nomads of northern Mali, ${ }^{44}$ the FLN, upon Algerian independence in July 1962, began to focus its interference on Niger. ${ }^{45}$ The two governments were not each other's natural ally as the PPN had shown little sympathy for the FLN's cause. 
While it recognised Algeria's independence rather quickly, this was done primarily because it worried about the possibility of Algerian infiltrations among its nomadic population and the relations Algiers might establish with Sawaba. ${ }^{46}$ Niger's regime feared, in particular, the rise to power of Ferhat Abbas and Ben Bella, as it though this could lead to concrete assistance being given to its domestic foe. ${ }^{47}$

From the summer of 1962, the Algerians got bolder, infiltrating as far south as the Tahoua region ( $300 \mathrm{~km}$ south-west of Agades) and contacting the Arabic-speaking population there. Different groups of people were used to undertake these infiltrations. Elements of the 'ALN' (the FLN's army), based in the Hoggar (Ahaggar) mountains in southern Algeria, made propaganda among the Tuareg of $\mathrm{N}_{1} g e r$, stressing the traditional links between the Tuareg population of Niger's Air region and their northern brethren in the Hoggar. ${ }^{48}$ Algerian traders were also active on behalf of the FLN, spreading propaganda and collecting money inside Niger. Finally, the assistant to the 'Aménokal' (supreme chief) of the Tuareg (Kel Ahaggar) in the Hoggar was arrested by Niger's authorities, accused of inciting 'their' Tuareg to opt for Algerian citizenship. ${ }^{49}$

The Algerians also encroached by military means. From Tamanrasset, the ALN moved south to establish a border post at In Guezzam, just inside Algeria, which led the Commandant de Cercle of Agades to ask for the establishment of a military post at In Abbangarit, $250 \mathrm{~km}$ north-west of Agades. In the end, the Nigériens set up a small station close to Assamaka, south of the border and fifty $\mathrm{km}$ from In-Guezzam, to control and tax the incoming caravans and stem the inflow of FLN propagandists that accompanied them. ${ }^{50}$ Yet, the frontier remained highly permeable. On several occasions, small armed detachments of the ALN crossed the border with vehicles, penetrating as far south as In Abbangarit, an area that had traditionally been roamed by Tuareg from the Hoggar (the Kel Ahaggar). In June 1963, one Tuareg chief, of the Kel Tadele tribe, claimed that Algerian soldiers travelling in four Land-Rovers had asked him for information about water points in the Ténéré - the vast desert of sand dunes between Agades and the eastern oasis of Bilma, nearly $500 \mathrm{~km}$ south-east of the Algerian frontier! ${ }^{51}$ The purpose of these incursions appeared to be to assert sovereignty over, or at least claim the loyalty of, parts of Niger's population, using the traditional rights of nomads to buttress these claims. In the process, the Algerians made arrests, confiscated vehicles and even ran into Niger army patrols, which did not feel secure enough to force a show-down. The Algerian government also used softer methods to assert their influence, enticing people with food donations or visits from political dignitaries. For example, the Aménokal of the Kel Ahaggar, Bey ag Akhemouk, and vice-president of Algeria's national assembly, visited the population of In Abbangarit and the Air region in June 1963. ${ }^{52}$

The PPN regime reciprocated these intrusions to a limited extent, engaging in espionage and pursuit of 1 ts opponents in Algeria. When Algeria expelled unemployed Nigériens from Tamanrasset, the police commissioner of Agades, together with its Commandant de Cercle and the local PPN secretary, travelled to the Algerian town, officially in order to help in the repatriation of their unemployed countrymen but secretly to collect intelligence on the activities of Sawaba. This was the primary concern of the government in Niamey, rather than the expansionist designs of the Algerian government itself. While the Agades delegation was respectfully welcomed by Tamanrasset's sous-préfet, 'Abdul Aziz', the Algerians were unable to prevent the Nigériens from discovering that the town's authorities were assisting Sawaba's activities (on which more below): the men from Agades cornered a Nigérien living in Tamanrasset, threatened and interrogated him, and obtained extensive details of Sawaba's clandestine operations in both Algeria and Niger. Upon their return to Agades, they duly reported to the minister of the interior. ${ }^{53}$ In addition, information on Sawaba came from the intelligence networks of the French, ${ }^{54}$ who still had many of their nationals working in Niger's administration and maintained military bases there right up to the end of 1964. Moreover, there is a possibility that part of the intelligence came from the continued substantial French presence at the nuclear testing site at In Eker, just north of Tamanrasset. ${ }^{55}$

\section{Sawaba Underground: A General Outline}

In the fluid context of Nigéro-Algerian interactions, Sawaba tried to organise and maintain its clandestine operations. Firstly, it tried, under very difficult circumstances, to keep its domestic organisation going. Party cadres met each other regularly, occasionally in minor towns but especially at Maradi, Zinder, Agades and, in particular, the capital where the party structure remained intact. ${ }^{56}$ An important task was the liaison "work with the leaders in exile, necessitating regular travel from Zinder, Niamey or other cities, to Gao, Bamako (where Bakary was based for some time) Tamanrasset, and Kano, from where Ousmane Dan Galadima, Sawaba militant and later chief of staff of the guerrillas, organised the party's presence. Bus and lorry drivers loyal to the party, in addition to postal workers, were used for liaison duties. ${ }^{57}$ Secondly, concrete opposition was undertaken through a variety of activities, ranging from symbolic resistance through attempted boycotts of official festivities to the collection of funds for the families of imprisoned activists. Agitation took place through the spreading of rumours, distribution of photographs of Bakary and the dissemination of clandestine tracts. ${ }^{58}$ Finally, the party engaged in tangible subversion, inciting prisoners to rebel against prison conditions, contacting disgruntled members of the military and infiltrating into the PPN. These infiltrations succeeded to an extent, notably among members of the local administration of Maradi. ${ }^{59}$

However, Nigérien and French officials, many of whom remained in command positions during the early $1960 \mathrm{~s}$, tried to make life as difficult as possible for Sawaba's partisans. Leaders were arrested on trumped-up charges, bank accounts seized and cars confiscated. Foreign nationals loyal to Sawaba were expelled, houses searched, and activists placed under house arrest, sentenced and incarcerated, either in civilian prisons or in internment camps in the Sahara, notably at Bilma. On numerous occasions, Sawabists were maltreated or tortured. ${ }^{60}$ As a result, the party was driven further underground, necessitating the avoidance of communication by ma1l. If the party was to survive, it needed forergn bases, backing and training facilities. Thus, early on Sawaba implemented 'Opératıon Formation Cadres', which aimed at training people who could take over government machinery once 
the party had retaken power. Numerous young men were sent to Eastern Europe to obtain vocational or university education, in addition to trade union and political training. ${ }^{61}$ The execution of this plan used networks of sympathisers who provided false identity papers and assisted recruits in leaving Niger. Other Sawabists received them in towns in Mali, Ghana or Nigeria where the party had a presence. In addition, several hundred men were recruited for military training, which took place in Algeria (discussed in the following section), Ghana, China, North Vietnam and, possibly, Poland. ${ }^{62}$

As mentioned above, Sawabists abroad established small stations, or hubs, in a number of cities. Those close to the frontier with Niger were Gao, Kano and Tamanrasset. These functioned for the collection of intelligence, reception and transfer of recruits, the organisation of infiltration missions and, at least in the case of Kano, for the arrangements of banking facilities and strategy meetings. There were also stations in cities further afield, the most important of which were Bamako, Algiers and the Ghanaian capital Accra. These formed important relay points between Sawaba and its Malian, Algerian and Ghanaian hosts, as well as its allies in the Eastern Bloc. They also welcomed recruits and transferred the necessary funds. In addition, the Accra base redirected commandos, upon completion of military training in Algeria, China and North Vietnam, to additional training in Ghana. ${ }^{63}$ All in all, at least several hundred people were involved in these operations. ${ }^{64}$

\section{Sawaba and Algeria}

Sawaba's cells in Algeria did not play a direct role in the invasion of Niger that was launched in the autumn of $1964 .{ }^{65}$ The Algerian government pursued a double-track policy, on the one hand maintaining diplomatic relations with the PPN regime and on the other hand testing Niger's resolve by violating the common border and questioning Niger's sovereignty over part of its northern regions. Assistance to Sawaba fitted well in this context and took different forms.

Contacts between Sawaba and the FLN were established at the highest level. Ousmane Dan Galadima met with Ben Bella at Casablanca airport in 1962, while Bakary met the FLN leader in Oujda, Algeria, in the same year. ${ }^{66}$ The key Sawabist in Algeria was Abdoulaye Mamani, the party ideologue based in the capital Algiers. Mamani settled in Algeria probably after the end of 1961. By the spring of 1963 he directed the party's organ, Sawaba, published in Algiers, maintained contact with the FLN and other foreign backers and negotiated the purchase of arms to be dispatched to Ghana ${ }^{67}$ The role of Sawaba's cells in Algeria was threefold. Firstly, they acted as antennas, picking up intelligence about the situation in Niger. Secondly, they formed launch pads for infiltration missions. However, although the frontier with Niger was highly permeable, only small-scale infiltrations were possible, aimed at the collection of intelligence or the maintenance of political contacts. ${ }^{68}$ Because the terrain was that of the central Sahara, a guerrilla invasion into Niger from Algeria was very difficult, especially for cadres who, raised in the Sahelian zone, were not used to the harsh conditions of the desert. Moreover, since in 1964 the French were still in control of the nuclear testing site at In Eker just north of 'Tamanrasset, an invasion from Algeria could have been betrayed quickly. The real onslaught on the PPN regime was therefore planned from Niger's southern and western borders. Thirdly, Sawaba's Algerian cells functioned as contact points for the reception of recruits and their dispatch to training institutions in the north of Algeria.

Tamanrasset was, therefore, primarily a transit point for intelligence and people. Sawaba's station there was manned by two men - Louis Bourgès, a half-caste from Agades who had been trained as a mechanic and driver and acted as liaison officer, and Boukari Karemi alias 'Kokino', who was the 'permanent', or paid official, of the local party office. ${ }^{69}$ Together they led party meetings, which took place at a house rented by Tamanrasset's deputy mayor, 'Soulémane'. Kokino and Bourgès liased with Algerian officials, such as Abdul Aziz, the sous-prefet mentioned above. These relations went much further than Algeria's 'benevolent neutrality', as was thought by French intelligence. Thus, the Tamanrasset authorities themselves sold Sawaba membership cards and provided the Sawaba cell in Tamanrasset with funds. When the Agades authorities visited Tamanrasset on their reconnaissance mission, the latter's police commissioner, who was the brother of the sous-preffet gave warning to Bourgès and Kokino, so that they could flee or go into hiding. Moreover, during their infiltrations into Niger Sawaba activists sometimes wore uniforms, presumably of the ALN, while in one instance FLN and Sawaba elements together infiltrated into Tabora, a locality in Niger on the desert track between In Abbangarit and the Algerian frontier post In-Guezzam. ${ }^{70}$

Sawaba's hub in Tamanrasset linked up with numerous towns in Niger. A key place appears to have been In Gall, an oasis $100 \mathrm{~km}$ west of Agades, located on an old desert track connecting Tamanrasset, In-Guezzam and southern Niger. All correspondence between Sawabists in Tamanrasset and Niger came through this place, where it was received by an Arab inhabitant who passed it on. ${ }^{71}$ Nigérien intelligence identified at least seven people who were part of the In Gall cell, one of them, a cattle trader called Kollo, being responsible for sending letters to Tamanrasset and receiving money for propaganda among the area's nomads. ${ }^{72}$ But the Tamanrasset network extended much further south: besides In Gall and Agades, intelligence found its way to and from Tamanrasset and Bilma, Teguidda, the eastern cities of Zinder, Tessaoua, Magaria and Goudoumaria, the central towns of Maradi and Madarounfa, as well as the western town of Dogondoutchi. The Dogondoutchi cell comprised a butcher by the name of Abdou, who together with a 'dioula' (itinerant trader) from Tahoua, collected intelligence from all districts in the country, as well as government ministries in Niamey. Abdou travelled personally to Tamanrasset to get in touch with Louis Bourgès. Thus, Tamanrasset was responsible for a vast intelligence network that partly overlapped with the party's station working from Kano in Northern Nigeria. Letters, photographs, propaganda material and money were carried southwards. In return, information found its way to Tamanrasset and on to Mamani in Algiers, who informed Ousmane Dan Galadima and Djibo Bakary. Local party activists also travelled in person to Tamanrasset to receive instructions, furnish the Algerian station with information or transmit messages for the party leadership. Traders and drivers kept the network running. $^{73}$ 
The city of Agades occupied an important place in this Sahelian-Saharan network, as it was a hotbed of domestic opposition itself, fuelled by the malaise reigning in the town. Even though unemployment was rife, the minister of the interior banned local Nigériens from travelling to Algeria in search of work, for fear of Algerian interference. Discontent, exacerbated by bad administration, sometimes erupted into open demonstrations. The population was pressed to contribute substantial sums to party coffers, with vulnerable groups such as prostitutes coerced to make monthly payments. Youngsters were forced to participate in 'psycho-political' information meetings aimed at fighting Sawaba influence. Tax collection was harsh, while the social climate worsened as a result of arbitrary arrests, including Tuareg dignitaries. ${ }^{74}$

The city therefore constituted fertile ground for Sawaba's agitation. Activists held numerous meetings both in the town and its vicinity, assembling Nigériens as well as local Algerians. They were in regular touch with Kokino and Bourgès in Tamanrasset Arms smuggled into Niger from Algeria, besides Libya and Chad, were rumoured to be destined for the party. By the spring of 1963, French intelligence considered Agades a 'sensitive zone', as local Tuareg chiefs deposed by the government would have aligned with Sawaba. While it was feared that these Tuaregs might link up with their brethren across the border in Algeria, the French still though that a Sawaba revolt by way of a Tuareg rebellion would risk the integrity of the Niger state and was therefore not considered by Sawaba as in its interests. ${ }^{75}$ Nevertheless, Sawaba did try to mobilise support in the country's northern regions. By the end of 1963, less than a year before the invasion, the party sent a hardened militant to Niger to assess the strength of the regime. Djibo Issa, an apprentice driver and mechanic from Dosso district in southern Niger and a contact of Louis Bourgès, flew to Algiers and then went on to Tamanrasset. From there, he drove by car to Niger, with uniforms and propaganda stuffed in his luggage. However, in In Abbangarit his car apparently broke down and Issa tried to steal the Land Rover from a local European mechanic. When this failed, he was arrested. ${ }^{76}$

While Sawabists risked capture when infiltrating inside Niger, the reverse was the case in Algeria. One Niger intelligence report noted that Nigériens travelling on the route Algiers - In Salah - Tamanrasset were stopped, checked and shown the photograph of Djibo Bakary. If they did not recognise him, they were maltreated and sent back north. ${ }^{77}$ It is very possible that this was done by the Algerian authorities working in collusion with local Sawabists, fearing Nigérien/French espionage.

In addition, the party had training facilities in northern Algeria at its disposal (see below). One of Abdoulaye Mamani's most important tasks was the reception of recruits. At times, the recruitment of guerrillas or commandos took place in Algeria itself. For example, probably somewhere in 1963 young unemployed Nigériens in Algiers, ready to leave for Agades, were seen to be enticed by Mamani to join up, while others asked of their own accord to be enlisted. While Mamani was saluted by these recruits and told those, who were willing to join up, to wait until there were places in the training camps, another group of 250 to 300 men was spotted, commanded by an Algerian. ${ }^{78}$ Although these men probably all came into the country through Tamanrasset, recruitment for Sawaba's guerrilla force through the desert town may not have been more than marginal, its primary function lying in intelligence work.

As shown below, recruitment for the training sites usually took place in Mali or Ghana, where the cadres were vetted and processed. From there, they were dispatched to North Africa. Most cadres travelled by ship from the Ghanaian port of Takoradi to Casablanca, where they were welcomed by Ousmane Dan Galadima, temporarily based in Rabat ${ }^{79}$ From there, they took the train to the Algerian frontier town of Marnia, the birth place of Ben Bella. ${ }^{80}$ Others went by plane from Bamako to Morocco, travelling on Malian passports ${ }^{81}$ or, more rarely, were recruited in Morocco while studying on a scholarship there. ${ }^{82}$ The Moroccan transit point was disrupted, however, with the outbreak of the Algero-Moroccan frontier war (1963). Thus, a party of trained recruits returning to Ghana got marooned in Morocco when Rabat refused to pay their return to Takoradi. Financial intercession by the Chinese embassy managed to break the deadlock. ${ }^{83}$ Mamani telephoned Galadima from Algiers during the war, ${ }^{84}$ probably to discuss its implications for recruitment. Some recruits then travelled by boat from Algiers to Marseille and on, directly to Ghana, avording Moroccan ports. ${ }^{85}$ Marseille appears to have been a regular transfer point linking Sawabists in Algeria with their comrades in West Africa. This was a dangerous point of the journey as the cadres were closely watched by French intelligence and occasionally searched and interrogated. There is evidence that intelligence gathered in this way was transmitted directly to the authorities in Niger. ${ }^{86}$

Sawaba's training in Algeria consisted of different activities - military, political and technical, and took place at different locations. Military training and political education took place mainly at Marnia, a training site not just for Nigériens but for 'toute l'Afrique combattante'. ${ }^{87}$ Hence, there were people from Angola, South Africa, Mozambique, Saõ Tomé, Cameroon and probably several other countries. Algeria at the time assembled revolutionaries from all over Africa, so that Sawabists in Marnia or Algiers met in person with people like Nelson Mandela, Che Guevara, Holden Roberto, Jonas Savimbi, Amilcar Cabral and Samora Machel. ${ }^{88}$ While most recruits were trained at Marnia, some may also have been instructed in Tiare (like Marnia in the département of Oran), the Algerian 'Etat Major' in Oran itself, and at a military training ground in the capital. ${ }^{89}$ Training at Marnia, of which Nigérien intelligence was aware, ${ }^{90}$ had a strong emphasis on military skills, although political formation was not forgotten. It involved mainly classical guerrilla tactics and included the handling of guns and other weapons, the construction of bombs, the use of hand grenades, the organisation of ambushes and the laying of mines. ${ }^{91}$ Recruits wore uniforms, very likely of the ALN, and received instruction from Algerian military of all ranks. ${ }^{92}$ Some claim, and there is evidence to this effect, that Sawaba's recruits were temporarily integrated in Algeria's armed forces, receiving army pay, ${ }^{93}$ subjected to the command of ALN officers and sometimes forced to serve as their domestics. ${ }^{94}$

Training was real and serious, extending from one month to nearly a year (for some possibly two years), with an average of four to five months. ${ }^{95}$ While limited in time, it included shooting practice and expeditions in the mountains. ${ }^{96}$ This contrasted with training in Nanking and the North Vietnamese camp of Son Tay, 
which according to some was more 'theoretical', ${ }^{97}$ with a strong emphasis on political indoctrination. Training in China and Vietnam was mostly meant for Sawaba's higher cadre - the middle cadres being instructed in Algeria, involving probably severa hundred men ${ }^{98}$ Moreover, Algerian training was only the initial phase, as instruction of the guerrillas continued upon their arrival in Ghana. In addition to ordinary military instruction in Marnia, several recruits received training at the 'Ecole des Transmissions' in Algiers. Here they learned the military uses of radio communication, including codes and Morse, instruction that took another five to six months to complete. ${ }^{99}$ The majority of Sawabists received their Algerian training in the years 1962 - upon Algeria's independence - and 1963, with some continuing training into 1964. While there were hundreds of Sawaba commandos still in training in Ghanaian camps after the failure of the autumn 1964 invasion, ${ }^{100}$ it seems that the great majority of trainees had by then left Algeria and, indeed, perished or been repulsed in the course of the attacks.

The role of Algeria in Sawaba's war against the regime in Niger was, therefore, of considerable if indirect importance. Both training in the camps of northern Algeria and the conduct of infiltrations from Tamanrasset continued at least untll the end of 1963, if not longer, i.e. less than one year before the invasion took place. At the level of its highest leader, Djibo Bakary, Sawaba's all-out attack on the PPN regime was at least partly inspired by the example of the Algerian revolution, as can be gauged from the order to one of his principal guerrilla officers, Salle Dan Koulou, to institute the 'wilaya' system of autonomous regions in areas of Niger that would have been liberated had the invasion been successful. ${ }^{101}$ The close involvement of the Algerian military in the run-up to the invasion even led to rumours that Algerian forces would join the rising once it had begun. ${ }^{102}$ Yet, for sound geographical reasons, an Algerian 'front' never actually materialised throughout Sawaba's guerrilla campaign against the PPN (1962-1966). Neither Tamanrasset nor Agades was involved in the actual fighting that took place along the entire length of Niger's southern and western frontiers. Sawaba's stations in Kano and other towns in Nigeria, Dahomey and Mali played the crucial part in the invasion as such. The party's Algerian bases played vital preparatory roles.

\section{Concluding Reflections}

The factors that were responsible for the failure of the 1964 invasion, which involved several hundreds of commandos, fall outside the scope of this article. ${ }^{103}$ Those who were repulsed and managed to flee across the border faced many years of exile, as did the party's activists who stayed behind in Ghana and Algeria. Thus, two years after the aborted invasion, one of Sawaba's men in Tamanrasset, Kokino, was still wanted by Niger's Surreté. ${ }^{104}$ The guerrillas who were captured were subjected to severe interrogation by PPN militias and the men of the 'Bureau de coordination', an organ of Niger's Sûreté staffed with French officers. Beatings and torture took place under the supervision of these officers, some of whom boasted to Sawaba prisoners that they had obtained enough training in this work in Madagascar, Vietnam, as well as Algeria, to break them. ${ }^{105}$
The failure of the rebellion had considerable implications, both for Sawaba and Algero-Nigerien relations. When another attack on the regime, by way of an attempted assassination of Diori, Niger's head of state, backfired in April 1965 the diplomatic context of Sawaba's struggle deteriorated sharply. Niger's regime sought closer ties with Northern Nigeria, improved its ties with Mali, Dahomey and Upper Volta, and with the help of its West African allies attempted to corner the regime of Ghana for its support to the revolt.

Then, in June 1965 Sawaba's safe haven of Tamanrasset was the scene of another remarkable event. Barely seven years after French generals had met in the Algerian desert town to plan the eviction of the Sawaba government, President Diori came north to pay his first visit on Ben Bella. ${ }^{106} \mathrm{He}$ confronted the Algerian leader with a memorandum containing details of Algeria's support for Sawaba. Ben Bella, the FLN revolutionary, would have listened with a mixture of sincerity and irritation and promised to discontinue all military aid to Sawaba, though he refused to deprive its activists of political asylum. In the wake of this meeting, Ben Bella's foreign minister, Abdelaziz Bouteflika, called in Abdoulaye Mamani, showing him a copy of Diori's memorandum and telling him that support would henceforth be political rather than military. ${ }^{107}$

This essentially conformed to the double-track policy the Algerians had pursued all along. It enabled them to cut their losses and continue their ties with the PPN, now that the overthrow of the government in Niamey had failed. A few days afterwards, however, Niger's political situation was, once more, affected by a major transformation in Algeria. The hero of the Algerian revolution, Ben Bella, was himself toppled in an army coup. His successor, Boumédienne, desired to improve Algeria's ties with other African states and let it be known that, from now on, Sawaba's cadres also had to desist from political activity in return for their right of abode. Since all Sawabists, especially those who had been involved one way or the other in the rebellion, risked the vengeance of the PPN, those enjoying Algerian hospitality were constrained to stop their political work and maintain a low profile. Abdoulaye Mamani continued to live and work as a journalist in Algiers, while Djibo Bakary visited Algeria for a short stay in $1966 .{ }^{108}$ In 1974 both men returned to Niger after the coup d'état of Seyni Kountché - a decision that would land them in prison quickly afterwards, ${ }^{109}$

In conclusion it can be said that, during the late 1950s and the larger part of the 1960s, Algerian and Nigérien politics were intricately connected. To some extent, this was caused by aspects peculiar to the character of the border region, which continued to affect the politics of the region in subsequent decades. The political geography of the Sahara, still marked by nomadic life styles, allowed and continues to allow for political loyalties irrespective of state boundaries and contrary to the concept of territorial sovereignty. Yet, the connections, incursions and infiltrations taking place between Algeria and Niger during the early 1960s were also part of the nature of Africa's independence politics, which in its early stages was marked, notably in West Africa, by rather fluid geographical boundanes, uncertanty about the effective extent of state influence and, hence, experiments to assess one's actual power. By the mid 1960s, African states had tested the extent of their control and, in some cases more than others, consolidated their positions. 
Niger, however, was to remain precariously dependent on French benevolence for the duration of the PPN regime (1958-1974), while the French managed to consolidate their influence over the country. Algeria was unable to affect decisively this power calculus and, with Boumédienne's accession to power, moved closer to a definitive settlement of its relations with Niger. This also accommodated the interests of France, which in 1967 gave up control over its Algerian nuclear testing site, just north of Tamanrasset. This merely constituted a southwards shift of France's strategic interests in the region, which became focused on the mining of uranium at the town of Arlit, to the north of Agades in northern Niger.

\section{NOTES}

1. Interesting insights in this can be gained from later autobiographies of French politicians and officials such as Foccart, Messmer, Salan, and De Gaulle himself. See further below.

2. The most thorough analysis of this is M. Djibo, Les transformations politiques au Niger à la veille de l'indépendance (Paris: L'Harmattan 2001)

3. It was only commented on by journalists, the most detailed account being G. Chaffard, Les carnets secrets de la décolonisation, vol. 2 (Paris: Calmann-Lévy 1965), pp. 269-332. Marred by inaccuracies, other accounts were affected by the Cold War and thus openly hostile to Sawaba. For an outline of these accounts, see K. van Walraven, 'Sawaba's Rebellion in Niger (1964-1965): Narrative and Meaning', in J. Abbink, M. de Bruijn and K. van Walraven (eds.), Rethinking Resistance: Revol and Violence in African History (Leiden and Boston: Brill 2003), ch. 9.

4. This article is based on archival research and fieldwork, as input for a monograph on the rebellion. . Besides interviews, a broad range of archival sources was consulted for this, including the Archives Nationales du Niger (hereinafter as ANN), the French Archives Nationales - Section Outre-Mer, Aix-en-Provence (hereinafter as ANSOM) and the Service Historique de l'Armée de Terre, Vincenne (hereinafter as ANSHAT). Also see R.B. Charlick, Niger: Personal Rule and Survival in the Sahe (Boulder, San Francisco and London: Westview Press 1991), p. 46.

6. A typical example of the latter would be Dandouna Aboubakar. Interviews with Ali Amadou and Abdou Adam, Niamey, 31 January and 29 November 2003 respectively.

See in that vein F. Fuglestad, 'Djibo Bakary, the French, and the Referendum of 1958 in Niger', in Journal of African History XIV/2 (1973), pp. 313-330.

8. Parti Sawaba du Niger: Pour Un Front Démocratique de la Patrie (Bureau Politique: Niamey 1962). . Djibo (note 2), pp. 60-61; C. Fluchard, Le PPN-RDA et la décolonisation du Niger 1946-1960 (Paris: L'Harmattan 1995), p. 228.

0. Le chef du territoire du Niger, P. Bordier, à Monsieur le Haut-Commissaire de la République en A.O.F., 20 mai 1957. Très confidential, ANSOM, FM Aff. Pol. Cart.2.187/Dos.7. Attached to this is a Synthèse des événements politiques qui ont précédé au Niger l'élection du conseil du Gouvernement. Très confidential. Oddly, while a rich source on urban warfare in the 1950s, these reports have never been used. Djibo (note 2), p. 74, does not discuss their content.

11. Djibo (note 2), p. 73; Fluchard (note 9), pp. 218-224.

12. Fluchard (note 9), p. 230.

3. Like Dandouna Aboubacar and Ousmane Dan Galadima. Djibo (note 2), pp. 73-74.

4. See I/D 2 juin 1958. Strictement Confidentiel. L'Inspecteur de la France d'outre-mer Marcel Boyer à Monsieur le Ministre de la France d'outre-mer Paris. Objet: Incidents au Niger, ANSOM, FM Direction du Contrôle Cart. 1.041, Mission Boyer, and FM Aff. Pol. Cart.2 255/Dos.2 (for latter dérogation 28 October 2003). Interviews confirm Sawaba's responsibility. Interview with Elhadj Illa Salifou,

15. An uni, 25 Nouch

1. An undentifed person even took photographs of French-led forces chasing rioters. I/D 2 juin 1958. Strictement Confidentrel. L'Inspecteur de la France d'outre-mer Marcel Boyer à Monsieur le Ministre 16. Djibo (note 2), p. 70.

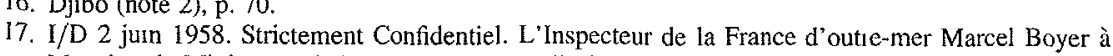
Monsieur le Ministre de la France d'outre-mer Paris. Objet: Incidents au Niger-

18. As noted by the French military in Algeria in 1959. Djibo, (note 2), p. 86, n. 2.
19. Djibo (note 2), p. 86. See also Communiqué Political Bureau, Sawaba, Bamako, 30 October 1961, in Gaskya. Organe Officiel du Parti Sawaba 16 (30 October 1961), pp. 1-2.

20. Djibo (note 2), p. 189 and G. Pallier, 'L'uranium au Niger', Les cahiers d'outre-mer, 37/146 (1984), p. 175.

21. At Reggane, 13 February 1960, from plutonium produced from France's domestic uranium supply. The project had commenced under the 4th Republic. Actual uranium mining in Niger commenced only in 1971. http://www.nuclearweaponarchive.org/France and Atlas du Niger (Paris 1971), p. 43. Djibo (note 2), p. 87, adds Niger's potential role in providing space to station French troops or nuclear testing, though I have not found explicit French statements to that effect.

22. French intelligence reports of the period (military and of the 'Service de documentation extérieure et de contre-espionage' - SDECE) are littered with statements to that effect.

23. See on this point the revealing memoirs C. De Gaulle, Mémoires d'espoir. vol. 1 : Le renouveau 1958-1962 (Paris 1970), p. 60 and Foccart Parle, vol. 1: Entretiens avec Philippe Gaillard (Paris Fayard Jeune Afrique 1995), p. 158.

24. Thus, the retrospective argument of some authors that Sawaba's leader made a 'tactical' error by rejecting the Communauté idea is facile. See f.e. Charlick (note 5), pp. 50-51.

25. See also Djibo (note 2), p. 54

26. Chef du territoire du Niger à Monsieur le Ministre de la F.O.M., Paris, et M. Le Haut Commissaire de la République en A.O.F., Dakar, 9 août 1958, ANSOM, FM Aff. Pol. Cart.2.181/Dos.1/Bis

27. Organisation commune des régions sahariennes (OCRS). Aperçu sur la Situation Politique du Territoire du Niger Durant la période du 15 novembre 1957 au 31 décembre 1957. Confidentiel, ANSOM, FM Aff, Pol. Cart.2.154/Dos.3, and letter of governor of Niger to France Outre-Mer, 18 January 1957, ANSOM, FM Aff.Pol. Cart.2.198/Dos.2

28. Direction des Services de Sécurité de 1'A.O.F.: Bulletin d'Information du 15 août au 20 septembre 1958, ANSOM, FM Aff. Pol. Cart.2.248.

29. See Direction des Services de Sécurité de l'A.O.F.: Bulletin d'Information du 15 août au 20 septembre 1958; Recueil des principaux renseignements reçus par le Bureau d'Etudes de l'A.O.F, pour la période du 15 au 21 Septembre 1958 (Haut-Commissariat de la République en Afruque Occidentale Française - Conseiller Politique - Bureau d'Etudes) no. 6, ex. no. 38, ANSOM, FM Aff. Pol. Cart.2.248; Congrès constttutif de la section nigérienne du P.R.A.: Rapport de politique générale, Adamou Sekou, 29-31 août 1958, ANSOM, FM Aff. Pol. Cart.2.181/Dos.1/Bis; and Renseignements. Territoire du Niger, Direction des services de police, no. 1.485/PSC/RG, Niamey, 16 September 1958, ANSOM, FM Aff. Pol. Cart. 2.181/Dos.1/Bis.

30. The chapter on this in Foccart's memoirs is called 'Sept mois pour changer de régime' (note 23).

11. Sawaba was aware that it was a matter of submission. See Communiqué, bureau politique du Sawaba (15 September 1958), sixth section.

32. Foccart (note 23), pp. 153, 158,169-170, 223.

33. Message 5.674/CHI Genesuper Dakar à IFTOM Paris. Secret \& Urgent, 18 septembre 1958, ANSOM, FM Aff. Pol. Cart.2.195/Dos.1.

34. R. Salan, Mémoires, vol. 4 : Fin d'un Empire. L'Algérie, De Gaulle et moi. 7 juin $1958-10$ juin 1960 (Paris: Presses de la cité 1974), pp. 116-117.

35. Ibid. p. 117. Also Message 5.674/CHI Genesuper Dakar à IFTOM Paris. Secret \& Urgent, 18 septembre 1958 .

36. Salan (note 34), p. 117.

37. In the form of an official credit of 44 million francs demanded by Niger's newly appointed governor, end August-early September. Besides this, France's socialist party, SFIO, would have promised funds to Nigérien politicrans to vote 'yes' while funds were also disbursed by Côte d'Tvoire's leader Houphouett-Boigny, minister in the metropolitan government and loyal to De Gaulle. The sums involved are not known, but both Sawabists and members of other parties in Niger have testified
that such funds were disbursed. See Djibo (note 2), pp. 95-96. Guy Mollet remained silent on it in his memoires (13 mai 1958-13 mai 1962 (Paris: Plon 1962]).

38. Djibo (note 2), p. 95 to this effect cites documents, which, however, do not make clear whether or not an initial sum of 10 million was not disbursed previously.

39. The referendum as such falls outside the scope of this article. Suffice it to say that both French archives and memoirs of French politicians squarely belie the apologetic argument of Fuglestad (note 7) that the referendum and parliamentary elections of September-December 1958 were a farly clean affarr. 40. Djibo (note 2), p. 141.

41. A probably apocryphal statement attributed by a Sawabist to De Gaulle after the latter's meeting with Djibo Bakary in Dakar, a few weeks before the referendum. Ibid. p. 97. The AOF High Commissioner, 
however, later wrote this conversation was 'ambiguous' though 'very courteous'. P. Messmer, Les blanes s'en vont: Récits de décolonisation (Paris: Editions Albin Michel 1998), p. 153. Air is the mountainous region in Niger's part of the Sahara north of the ancient city of Agadez.

42. The French only abandoned In Eker in January 1967. http://www.nuclearweaponarchive.org/France.

43. Rapport de Fin de Commandement. 1ère Partie: Situation Politique et Militaire de l'Ex-Afrique Occidentale Française. Délégation pour la Défense de la Zone d'Outre-Mer no. 1. Etat Major. 2ème Bureau. Dakar, le 30 juin 1962, 5, ANSHAT, $5 \mathrm{H} 31$.

44. Although as of independence, the FLN began mending its fences with them. Bulletin de Rensergnements Hebdomadaire, no. 10, 2-8 juillet 1962, 2ème partie, 18, ANSHAT, 5 H 121.

45. Rapport de Fin de Commandement. 6ère Partie: Situation Polittque et Militaire de l'Ex-Afrique Occidentale Française. Délégation pour la Défense de la Zone d'Outre-Mer no. 1. Etat Major. 2ème Bureau. Dakar, le 30 juin 1962, ANSHAT, 5 H 31.

46. Bulletin de Renseignements Hebdomadaire, no. 25.314, no. 11, 9-15 juiliet 1962, lère partic, 5, ANSHAT, 5 H 121

47. Ibid., no. 25.379 , no. 14,30 jullet -5 août 1962, 2ème partie, 14 . In the autumn of 1962 these worries increased with the formation of a Political Bureau in Algiers faithful to Ben Bella. Ibid., no. 25.668, no. 23, 1-7 octobre 1962, 2ème partie, 22-23 (both ANSHAT, 5 H 121).

48. The French, however, questioned the loyalty of the Hoggar Tuareg to the authorities in Algiers. Rapport de Fin de Commandement du Général de Brigade Le Porz. Délégué pour la Défense de la Z.O.M. 4. du 1 avril 1962 au 30 jum 1963. Délégation pour la Défense de la Zone d'Outre-Mer no. 4. Etat Major. Ière Partıe: Situation Politique et Militaire de la Z.O.M. no. 4 (2ème Bureau) VIème Partie: Armées Nationales (3ème Bureau); VIIème Partie: Gendarmeries Françaises \& Nationales (Bureau Gendarmerie), ANSHAT, $5 \mathrm{H} 31$. Also note 45 above.

49. Bulletin de Renseignements Hebdomadaire, no. 25.345, no. 13, 23-29 juilet 1962, lère partie, 6, and no. 25.428, no. 16, 13-19 août 1962, 2ème partıe, 16 (both ANSHAT, 5 H 121).

50. Ibid., no. 25.547, no. 19,3-9 septembre 1962, 2ème partie, 26; no. 25.668, no. 23, 1-7 octobre 1962 , 2ème partte, 23; no. 25.842 , no. 28,5-11 novembre 1962, lère partie, 27; no. 25.940, no. 31,26 novembre-2 décembre 1962, 2ème partie, 33; no. 26.045, no. 33, 10-16 décembre 1962, 3ème partie, no. 26.051/2/SC (all ANSHAT, 5 H 121); no. 1.079, no. 35, 26 août-1 septembre 1963 , 2ème partie, 27, ANSHAT, 5 H 130

51. Ibid., no. 816, no. 26, 24-30 juin 1963, 2ème partie, 25, ANSHAT, 5 H 123. It was speculated that it could point to Algerians passing through Niger on their way to help the 'maquis in Cameroon, refer ring to the rebellion of the 'Union des Populations du Cameroun' (UPC), by then at a low level of activity

52. Bulletin de Renseignements Hebdomadaire, no. 777, no. 24, 10-16 juin 1963, 2ème partie, 19, ANSHAT, 5 H 123; no. 21, no. 1, 30 décembie 1963-5 janvier 1964, 2ème partie, 20, ANSHAT, $5 \mathrm{H} 125$

53. Ibid., no. 10,2-8 juillet 1962, lère partic, 6 , ANSHAT, 5 H 121; no. 2.382, no. 47, 18-24 novembre 1963 , 2ème partie, 25 and no. 2.415 , no. 48,25 novembre-1 décembre 1963 , 2ème partie, 22 (both ANSHAT, 5 H 125); Direction de la Sûreté Nationale/Commissariat de Police de la Ville d'Agadez: Notes d'Information Concernant le Sawaba en liaison avec Tamanrasset (1963), ANN, 86 MI $3 \mathrm{~F}$ 18.9

54. Documents in ANSHAT in Vincennes attest to this.

55. Data for this are lacking. With thanks to Jeremy Keenan for this point of information.

56. Interview with Mounkaila Beidari, Niamey, 2 November 2003.

57. K. van Walraven, 'Vehicle of Sedition: The Role of Transport Workers in Sawaba's Rebellion in Niger (1955-1967)', paper to the 1st European Conference on African Studies (AEGIS), London, 29 June- 3 July 2005 .

58. Recueil des principaux renseignements reçus par le Bureau d'Etudes pour la période du $25 \mathrm{Juin}$ au 1 Juillet 1959 (Haut-Commissariat de la République en Afrique Occidentale Francaise - Conseiller Politique - Bureau de Synthèse), no. 36, ex. no. 1. Secret, ANSOM, FM Aff. Pol. Cart. 2249; Recueil des principaux renseignements reçus pour la période du 10 au 16 Décembre 1959 no. 60, ex. no. 2. Secret, ANSOM, FM Aff. Pol. Cart. 2.251; ibid., 15 au 21 Janvier 1960, no. 64, ex. no. 27, Secret, ANSOM, FM Aff. Pol Cart.2 252; Bulletin de Renseignements Hebdomadaire, no 25.337, no 9, 25 février-3 mars 1963, 2ème partie, 24, ANSHAT, 5 H 123, ibid., no 882, no 29, 13-10 juillet 1964, 2ème partie, 19, ANSHAT, 5 H 127.

59. More spectacular were Sawaba plans to create a radio installation and sabotage attempts, early in 1959 and (possibly) in the summer of 1964, before the actual invasion. Recueil des principaux renseignements reçus par le Bureau d’Etudes pour la période du 30 Mars au 12 Avnl 1959 (Haut-Commissariat de la République en Afrique Occidentale Francaise - Conseiller Politique - Bureau de Synthèse), no. 26, ex. no. 1, Secret; Ibid., no. 42, ex. no. 1. Secret (both ANSOM, FM Aff. Pol. Cart.2.249); Ibid., no.

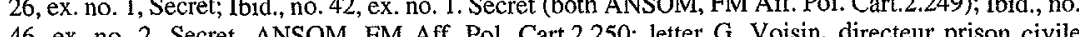
46, ex. no. 2, Secre, ANSOM, Niamey, to Commandant de Cercle Namey,

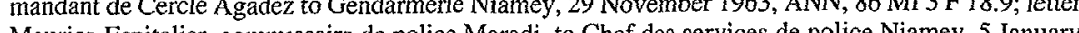
Maurice Espitalier, commissaire de police Maradi, to Chef des services de police Niamey, 5 January 1961, ANN, 86 M 3 F .8, Noe dis Rapport Annuel Annee 1964 - no. 436.8 Marad, ANN, Fonds DAPA, Bull. Mens. de Rens.; Bulletin 5 H 126.
denseigne.

60. Interviews with Sawabists in 2002-2003 point to maltreatment and torture, confirmed in archival sources. See, for example, Bulletin de Renseignements Hebdomadaire, no, 95, no. 4, 2ème partic, sources. See, for example, Bulletin de Renseignements Hebdomadaire, no. 95, no. 4, 2ème partic, 20-26 On Blm 1962) Niamey 1962), pp. 61 and 64, and Z.O.M. no. . Recuell des principaux cours de la priode 22-28 , and Z. Also Com pastomt Also Concte ZOM1/2, 27. ANSHAT 5 H 95 and Recueil des pincipaux renseignements recus pour la période du 5 au 11 Novembre 1959, no. 55, ex. no. 1, Secret, ANSOM, FM Pol. Cart.2.251.

61. It is difficult to give precise estimates, but the Sawaba students may have numbered at least 180 , a huge number when set against the underdeveloped state of Niger's economic and educational huge number when set against the underdeveloped state of Niger's economic and educational
system. Note d'information, 13 September 1961, ANN, 86 MI 3 F 3.5 (Niger's Sûreté file on Djibo Bakary).

62. Sawaba. Organe Central du Parti Sawaba du Niger, March 1963; Note d'information, 16 August 1961, ANN, 86 MI 3 F 3.10; ibid., 13 September 1961, ANN, 86 MT 3 F 3.5; and 18 October 1960, ANN, 86 MI 3 F 8.2 .

63. Minor cells were established in Lagos, Ouagadougou and Porto Novo, from where the invasion was directed in 1964. Sawaba also had a presence near smaller towns near the frontier with Niger in Northern Nigeria, Dahomey and eastern Mali, acting as arms depots and springboard for the invasion. Z.O.M. no. 1. Bureau de synthèse de l'Afrique Occidentale. Recueil des principaux renscignements Z.O.M. no. 1. Bureau de synthèse de l'Afrique Occidentale. Recueil des principaux renscignements
collectés au cours de la période $1-7$ février 1962, Secret, H.V. 5 , ANSHAT, 5 H 92; Ibid., 5-11 collo novembre 1950, 1960, no. 63, ex, no. 28, Secret, ANSOM, FM Aff. Pol. Cart.2.252; T.R. Shaw, British Embassy Abidjan, to C.M. Lequssy Abidjan to P.R.A. Mansfield, West \& Central Africa Department Warren, Brish Foreign Office London, 33 October 1964, Contidential, Public Record Office (hereinafter as PRO), London, FO 371/177.230: Political Relations: Rebel Troubles in Niger. Allegations of Chinese and 6 December 2003.

64. This is only a very rough, first estimate.

65. See for an outline, Van Walraven (note 3).

66. Interview with Bachir Boukary, Zinder 11 February 2003, J.P. Morillon, 'La tentative insurrectionelle du SAWABA', Est et Ouest 342 (16-31 May 1965), p. 22.

67. Interview with Ali Taba Niamey, 4 February 2003; Sawaba. Organe Central du Parti Sawaba du . Interview wa 1963. C Mancer Niger, May 1963 ; C. Maman, Répertoire biographque des personnalites de la classe politique el des leaders d'opinion du Niger de 1945 à nos jours, vol. I (Niamey: Editions Démocratie 2000

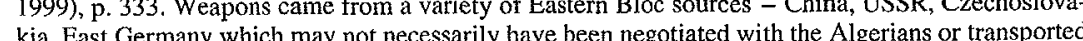
from from Algena to Go borders or inside Niger. Some middle cadres saw him - retrospectively at least - as a man 'who wrote books and wore a tie and like Djbo Bakary never vistted the guerrillas in 'des endroits saies'. Interrespectuvely.

68. Interview with Mounkalla Albagna, Niamey, 6 December 2003

69. Délégation pour la défense de la zone d'outre-mer no. 4 Etat-Major - 2ème burreau, Abrdjan, ?1964 Bulletin de Renseignements particulies, 18 octobre 1964, no. 1234/2/S - Note d'information Complôt contre ta sûreté de l'Etat: affaire Diallo (3-5 décembre 1963); subversion au Niger, parti 
Sawaba, attaques contre le Président Diori; organisation des forces de police, sûreté nationale, milices populaires (1959-66); ANSHAT 10 T 717, dossier 2, 3. “1964-1965" (dérogation 30 June 2004); Letter of Chef de Circonscription d'Agadez to M. le Ministre de l'intérieur, 26 June 1963, ANN, 86 MI 3 F 18.9; Fluchard, Le PPN-RDA, Annex 10.

70. Bulletin de Renseignements Hebdomadaire, no. 2.262, no. 44, 2ème partie, 21, ANSHAT, 5 H 131 and various documents in Notes d'Information Concemant le Sawaba en liaison avec Tamanrasset (1963), ANN, 86 MI 3 F 18.9 (note 53). While a friendly place for Sawaba, Tamanrasset, with an army contingent of thirty, was allegedly a hostile place for Europeans, who suffered confiscation of goods etc. Notes d'Information Concernant le Sawaba en liaison avec Tamanrasset (1963), ANN, 86 MI 3 F 18

71. Thus, Abdoulaye Mamani once undertook an infiltration mission from Tamanrasset and stayed in In Gall for four days. See following note.

72. Aboubakar, commissioner of police Agadez, to Directeur de la Sûreté Nationale Niamey, 6 November 1963 , in Notes d'Information Concernant le Sawaba en liaison avec Tamanrasset (1963), ANN, $86 \mathrm{MI}$ $3 \mathrm{~F} 18.9$

73. All this information was extracted by Niger's Sûreté from the Nigérien Yahaya Silimane, who was interrogated by the police commissioner of Agadez in the course of his visit to Tamanrasset. See Ibid.

74. Bulletin de Renseignements Hebdomadaire, no. 25.337, no. 9, 25 février - 3 mars 1963, lère partie, 7 and 2ème partie, 24-25; no. 25.434, no. 12, 2ème partie, 18-24 mars 1963, 21 -22; no. 25.463, no. 13, 15-21 mars 1963, 2ème partie, 25 ; no. 25.518 , no. 14, 1-7 aviil 1963, 2ème partie, 19-20; no. 710, no. 21, 20-26 mai 1963, lère partie, 5 and 2ème partie, 20-22, ANSHAT, $5 \mathrm{H} 123 ;$ no. 1.024, no. 33, 2ème partie, 25, ANSHAT, 5 H 124; no. 501, no. 17, 20-26 avril 1963, 2ème partie, $21 ;$ no. 673, no. 22,

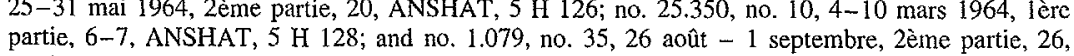
partic, 6-7, ANSHAT,
ANSHAT, 5 H 130 .

75. Aboubakar, commissioner of police Agadez, to Directeur de la Sûreté Nationale Niamey, 6 November 1963, Notes d'Information Concernant le Sawaba en liaison avec Tamanrasset (1963), ANN, 86 MI 3 F 18.9; Bulletin de Renseignements Hebdomadaire, no. 25.337, no. 9,25 février - 3 mars 1963, 2ème partie, 24; no. 25.434, no. 12, 18-24 mars 1963, 2ème partie, 21, ANSHAT, 5 H 123; and no. 25.350, no. 10, 4-10 mars 1963, lère partie, 6-7, ANSHAT, 5 H 128 .

6. Fiche de Renseignements, 23-25 November 1963, in Notes d'Information Concernant le Sawaba en liaison avec Tamanrasset (1963), ANN, 86 MI 3 F 18.9

7. Aboubakar, commissioner of police Agadez, to Directeur de la Sûreté Nationale Niamey, 6 November 1963, Notes d'Information Concernant le Sawaba en liaison avec Tamanrasset (1963), ANN, 86 MI 3

78. Aboubakar, commissioner of police Agadez, to Directeur de la Sûreté Nationale Niamey, 6 November 1963 (different letter, in same file [Notes d'Information Concernant le Sawaba en liaison avec Tamanrasset (1963), ANN, 86 MI 3 F 18.9])

79. For some time, Morocco was part of the left-leaning 'Casablanca bloc' of countries, which accounts for the hospitality given to militant nationalists from Niger. For several years, Morocco was also one of the countries where young Nigeriens (usually dispatched by Sawaba) were enrolled in institutions for secondary education. In a way this harked back to pre-colonial times when the country had intensive communication with regions south of the Sahara.

80. Interviews with Ali Amadou, Niamey, 28 January 2003; Noga Yamba, Zinder, 14 February 2003; and Mounkaila Albagna, Niamey, 29 November 2003

81. Interview with Ail Mahamane Madaouki, Zinder, 10 February 2003

82. Interview with Mounkaila Beidari, Niamey, 28 November 2003

84. Interview with Ousmane Dan Galadima, Madaoua, 7 February 2003.

85. Interview with Ali Amadou, Niamey, 28 January 2003.

85. Interview with Ali Amadou, Niamey, 28 January 2003.
86. Interview with Ousmane Dan Galadima, Madaoua, 7 February 2003; Fiche de Renseignements, 23-25 November 1963, in Notes d'Information Concernant le Sawaba en liaison avec Tamanrasset (1963), ANN, 86 MI 3 F 18.9; and Note d'information, 4 February 1960, ANN, 86 MI 3 F 8.6 (file Ousmane Dan Galadima)

87. Interview with Ali Amadou, Niamey, 28 January 2003.

88. Ibid.; interviews with Ousmane Dan Galadima, Madaoua, 7 February 2003 and Mounkaila Albagna, Niamey, 29 November 2003

89. Chaffard, (note 3), p. 309; interview with Mounkaila Beidari, Niamey, 28 November 2003; Le Niger, 16 November 1964 (text interrogation of captured Sawaba guerrilla, Dembélé Djibrilla).

90. Interview with Abdou Adam, Niamey, 29 November 2003.
91. Interviews with Noga Yamba, Zinder, 14 February 2003; Ali Amadou, Niamey, 28 January 2003; Ali Mahamane Madaouki, Zinder, 10 February 2003; Le Niger, 2 November 1964 (text interrogation Robert Seguinikin). In the wake of the 1964 invasion, an assortment of weapons was captured, such as sub-machine guns, 'PA's, grenades and various sorts of rifes. See, for example, Le Niger, 21 June 1965 .

92. Le Niger, 26 October 1964 (text interrogation Maman Alke) and interview with Ali Amadou, Niamey, 28 January 2003.

93. Morillon, 'La tentative insurrectionelle du SAWABA', and G. Comte, 'An Assassination that Failed', in National Review: A Journal of Fact and Opinion 7 (New York, 15 June 1965), p. 510.

94. As one Sawaba commando, Dembélé Djibrilla, later complained. Text of interrogation in Le Niger, 16 November 1964.

95. Le Niger, 26 October 1964 (text interrogation Maman Alke), 2 November 1964 (text interrogation Robert Seguinikin), and 16 November 1964 (text interrogation Dembélé Djibrilla); interviews with Ali Amadou, Niamey, 28 January 2003; Mounkaila Albagna, Niamey, 29 November 2003; Amadou Diop, Zinder, 13 February 2003; and Ali Mahamane Madaouki, Zinder, 10 February 2003. 6. Interview with Mounkaila Albagna, Niamey, Niamey, 6 December 2003.

97. In Nanking elbow protection gear would have been used at shooting practice and recruits were banned In Nanking elbow protection gear would have been used at shooting practice and recruits were banned 9. Abrying arms. Ibid. and text of interrogation of Hassane Djibo, in Fraternité Hebdo, 14 May 1965. 1963 speaks of 300 and in another letter with the same date reported the sighting, mentioned above, of 250 to 300 Sawaba recruits. Notes d'Information Concernant le Sawaba en liaison avec Tamanrasset (1963), ANN 86 MI 3 F 18 . Parties of thirty to fifty men at a time would travel from West Africa to Algeria. Interview with Mounkaila Albagna, Niamey, 29 November 2003.

99. Interviews with Ali Amadou (who spoke of a 'camp' rather than a school), Niamey, 28 January 2003; Int Albagna, Niamey, 29 November 2003.

100. For the continuance of training and attack planning, M. Dangaladima, Secrétaire Général Sawaba, to A.K. Barden, President Bureau of African Affairs, Accra, 31 October 1964, PRO, FO 371/177.230; Nkrumah's Subversion in Africa: Documentary Evidence of Nkrumah's Interference in the Affairs of Nkrumah's Subversion in Africa: Documentary Evidence of Nkrumah's Interference in the Affairs of
Other African States (Accra: Ministry of Information, n.d.), pp. 19-20, 89; Chaffard, (note 3), p. 326.

101. Djibo Bakary to Salle Dan Koulou, 22 September 1964. Text in Bulletin de Renseignement particulier, 10 octobre 1964, Secret; Complôt contre la sûreté de l'Etat: affaire Diallo (3-5 décembre 1963); subversion au Niger, parti Sawaba, attaques contre le Président Diori; organisation des forces de police, sûreté nationale, milices populaires (1959-66); ANSHAT $10 \mathrm{~T} 717$, dossier 2, 1. "Niger police, sûreté nationale, milices populaires (1959-66); ANSHAT $1964-1965$ ". For identification addressee and date, see Le Niger, 23 November 1964. For a discussion of this dimension, see Van Walraven (note 3), pp. 25I - 252 and generally F.D. Colburn, The Vogue of of this dimension, se Van Walraven (note 3), pp. $251-252$ and generally F.D.
Revolution in Poor Countries (Princeton: Princeton University Press 1994).

102. Bulletin de Renseignements Hebdomadaire, no. 25.145, no. 4, 21-27 janvier 1963, lère partie, 6 and Zème partie, 17, ANSHAT, 5 H 128 .

103. This is discussed in a monograph on the history of Sawaba (forthcoming). For an initial assessment Van Walraven (note 3) (based on published sources and hence somewhat affected by partisan, i.e. hostile, opinions about Sawaba of French and German journalists who uncritically worked in the Cold War context and, in some cases - such as Gilbert Comte - had close personal relations with people of the PPN regime).

04. Republique du Niger. Ministère de l'Intérieur. Direction de la Sûreté Nationale. Surveillance du Territoire (Bureau de Coordination), no. 396/SN/ST, 29/9/66: SECRET. ORGANISATION TERRORISTE "SAWABA" (Recueil des dirigeants et militants actifs en fuite); exemplaire no. 000148, destinataire le Sous Préfet de Dosso. Absent in the Archives Nationales du Niger, this document can be found in the archives of the Gendarmerie Nationale, Niamey. Personal copy provided by H.E. Sanda Mounkaïla, minister of youth affairs for UDFP-Sawaba (2003). Nothing i known of the whereabouts of Kokino or Louis Bourgès after the failure of the invasion.

105. Interview with Mounkaila Beidari, Niamey, 28 November 2003. He was injected with a serum and tortured.

106. Le Niger, 14 June 1965

107. Chaffard, (note 3), pp. 329-329

108. West Africa, 28 June to 4 July 1993 (with a necrology of Mamani); Chaffard (note 3), p. 331; G. Chaffard, 'La subversion au Niger en 1965', France-Eurafrique 190, (December 1967), p. 37.

109. In 1975, after rumours of a coup d'état in which Sawaba was most likely not involved. Many Sawabists who had stayed on in Ghana were forcibly returned to Niger after the President of for many years. 